\title{
Transformasi Sistem Pemanenan Latex Tanaman Karet: Review
}

\author{
The Transformation of Latex Harvesting System of Hevea Rubber Tree: A Review
}

\author{
Junaidi \\ Pusat Penelitian Karet, Balai Penelitian Sungei Putih, Galang, Deli Serdang, Sumatera Utara \\ Po. Box 1415 Medan 20001, Indonesia \\ E-mail Penulis Korespondensi: junaidi.sp5@gmail.com
}

Tanggal submisi: 27 Januari 2020; Tanggal penerimaan: 03 Juni 2020

\begin{abstract}
Most people understate that latex harvesting is merely cutting the bark and collecting the sap. Since it was cultivated in the monoculture plantation system, rubber (Hevea brasiliensis) harvesting system has been transformed continually. This article presents the transformation of rubber harvesting systems, tapping innovations that have been developed, and the current condition of rubber agribusiness and its impact on the tapping system applied. At the beginning of the development of the rubber cultivation era, tapping was conducted with multiple slicings to gain high rubber yield. This system turned into one slice to extend the economic span of the plant. The invention of latex stimulants transformed the rubber tapping system from once every two days (d2) without stimulants to once every three days (d3) with stimulants. In the case of the tapping technique, several tapping systems have been developed, including puncture tapping, upward and double-cut tapping, Alternate Tapping System, and Change Over Panel. Except for the puncture tapping, those tapping systems are still used nowadays. Latex diagnosis, that is the measurements of the sucrose, inorganic phosphate, and thiol contents in the latex, became the basis of clonal grouping and the clonal typology tapping system. The current low rubber price renders the adoption of low-frequency tapping systems $(d 4, d 5$, or $d 6)$ with high dose and frequency of stimulant application. In the future, the low-frequency tapping system will remain the ultimate choice as labor costs continue rising. Besides, the use of sensory technology and digital instruments is being widely studied, which indicates that the latex harvesting system in rubber plants is believed to continue to develop.
\end{abstract}

Keywords: Hevea brasiliensis, latex diagnosis, latex yield, stimulant, tapping

\begin{abstract}
ABSTRAK
Sebagian besar masyarakat beranggapan bahwa memanen lateks hanya mengiris kulit dan menampung getahnya. Namun sebenarnya, sejak dikembangkan dalam sistem perkebunan monokultur, sistem pemanenan lateks karet (Hevea brasiliensis) terus mengalami pembaharuan. Artikel ini menyajikan transformasi sistem pemanenan lateks tanaman karet, inovasi-inovasi yang pernah dikembangkan, serta kondisi agribisnis karet saat ini dan dampaknya terhadap sistem sadap yang diterapkan. Pada awal perkembangan perkebunan karet, penyadapan dilakukan dengan banyak irisan untuk mendapatkan hasil sebanyak-banyaknya. Ini kemudian berubah menjadi satu irisan untuk memperpanjang umur ekonomis tanaman. Penggunaan stimulan mengubah sistem penyadapan karet dari dua hari sekali (d2) tanpa stimulan menjadi tiga hari sekali (d3) dengan stimulan. Dalam hal teknis, beberapa sistem sadap pernah dikembangkan antara lain, sadap tusuk, penyadapan ke arah atas, sadap ganda, Alternate Tapping System, dan Change Over Panel. Selain sadap tusuk, inovasiinovasi penyadapan tersebut tetap digunakan sampai saat ini. Diagnosis lateks melalui pengukuran kadar sukrosa, fosfat anorganik, dan thiol dalam lateks, menjadi dasar pengelompokan klon dan penyadapan tipologi klonal. Harga karet yang rendah saat ini menyebabkan perusahaan perkebunan cenderung mengadopsi sistem sadap frekuensi rendah $(\mathrm{d} 4$, $\mathrm{d} 5$, atau d6) dengan dosis dan frekuensi stimulan yang tinggi. Di masa yang akan datang, sistem sadap frekuensi rendah akan tetap menjadi pilihan utama karena upah tenaga kerja terus meningkat. Selain itu, penggunaan teknologi sensorik dan instrumen digital mulai banyak diteliti. Melihat fakta-fakta ini, sistem pemanenan lateks pada tanaman karet diyakini akan terus berkembang.
\end{abstract}

Kata kunci: diagnosis lateks, Hevea brasiliensis, penyadapan, produksi karet, stimulan 


\section{PENDAHULUAN}

Kegiatan pemanenan pada tanaman karet (Hevea brasiliensis) sangat spesifik bila dibandingkan dengan tanaman perkebunan lainnya karena yang dipanen adalah metabolit sekundernya (cis-Polyisoprene) (Gronover et al., 2011). Berbeda dengan spesies penghasil lateks lainnya seperti guayule (Parthenium argentatum) dan Russian dandelion (Taraxacum kok-saghyz) yang merupakan tanaman semusim dimana ekstraksi lateks dilakukan dengan memanen seluruh bagian tanaman (van Beilen dan Poirier, 2007; Perumal et al., 2013), $H$. braliensis merupakan tanaman tahunan berumur panjang sehingga pemanenan lateks memiliki tantangan tersendiri yaitu mendapatkan lateks sebanyak mungkin dalam jangka waktu yang lama.

Biosintesis karet berlangsung dalam laticifer, sel khusus yang dimiliki oleh setiap spesies penghasil lateks (Prado dan Demarco, 2018). Pada tanaman karet, lateks dapat ditemukan hampir di seluruh organ tanaman meliputi akar, batang, cabang, daun, bahkan endosperm biji. Pemanenan lateks pada $H$. brasiliensis dilakukan dengan penyadapan yaitu mengiris kulit karet untuk mengeluarkan lateks dari jaringan tanaman. Penyadapan umumnya dilakukan di batang karena secara teknis lebih mudah dan dapat dilakukan dalam jangka panjang. Saat ini klon-klon yang dibudidayakan secara luas memiliki potensi produksi tinggi dan secara teoritis masih dapat ditingkatkan (Priyadarshan et al., 2009). Seiring tuntutan medapatkan lateks sebanyak mungkin, penyadapan dilakukan secara terstruktur meliputi panjang alur, frekuensi penyadapan, dan aplikasi stimulan.

Eksploitasi tanaman karet membutuhkan tenaga kerja dalam jumlah banyak. Stimulan lateks, bahan kimia mengandung etefon, pada awalnya diperkenalkan untuk mengurangi biaya tenaga kerja melalui pengurangan frekuensi sadap namun produksi tetap dapat dipertahankan. Saat ini aplikasi stimulan sudah merupakan bagian terintegrasi dari sistem sadap. Dalam kondisi dimana panjang alur dan frekuensi sadap tidak dapat dimodifikasi, aplikasi stimulan merupakan kunci pencapaian produksi di lapangan (Atminingsih et al., 2019).

Penerapan sistem sadap mengalami perkembangan signifikan dalam beberapa dekade terakhir. Beberapa modifikasi cara pemanenan lateks di antaranya sistem sadap tusuk (puncture tapping system) (de Soyza and Samaranayake, 1983), penyadapan ke arah atas (upward tapping system) (Obouayeba et al., 2008), penyadapan ganda (double cut tapping system) (Nhean et al., 2017), dan sistem sadap bergantian (alternate tapping system) telah diteliti dalam upaya meningkatkan produksi lateks. Sebagian teknik penyadapan tersebut terus digunakan hingga saat ini. Pendekatan fisiologi mulai mendapat perhatian setelah beberapa klon baru menunjukkan respons yang berbeda terhadap sistem sadap yang diterapkan. Hasil-hasil penelitian menunjukkan bahwa potensi klon dapat diotimalkan dengan sistem sadap yang spesifik. Hal ini mendasari penerapan sistem sadap tipologi klon yang membedakan pe- nyadapan berdasarkan tingkat metabolisme tanaman (Sumarmadji et al., 2012; Lacote et al., 2013). Meskipun sistem pemanenan lateks $H$. brasiliensis terus mengalami perubahan, prinsip dasar penyadapan tetap sama yaitu metode mendapatkan lateks sebanyak-banyaknya.

Sebagian besar masyarakat, bahkan sebagian praktisi dan akademisi, beranggapan bahwa penyadapan hanya mengiris kulit batang karet dan menampung getahnya. Namun sebenarnya sistem pemanenan lateks melibatkan banyak aspek yang menentukan produksi yang diperoleh. Artikel ini menyajikan perkembangan sistem pemanenan lateks $H$. brasiliensis, inovasi-inovasi yang pernah dikembangkan, serta kondisi agribisnis karet saat ini dan dampaknya terhadap sistem sadap yang diterapkan. Informasi ini bermanfaat bagi pelaku agribisnis karet, praktisi, peneliti, akademisi untuk memahami teknis pemanenan lateks, faktor-faktor yang mempengaruhi hasil, dan teknologi sistem sadap di masa yang akan datang.

\section{SISTEM SADAP TRADISIONAL}

Tonggak sejarah penyebaran dan budidaya tanaman karet adalah ketika Sir Henry Wickham (tahun 1876) mengumpulkan 70.000 biji karet dari hulu sungai Amazon di Amerika Selatan kemudian membawanya ke Kew Botanical Gardens di London, Inggris. Kecambahkecambah tersebut kemudian disebarluaskan ke negaranegara koloni Inggris pada masa itu meliputi Sri Lanka, Malaysia, Singapore, and India (Simmons, 2008; Priyadarshan, 2011). Tanaman karet pertama kali diintroduksi ke Indonesia dari Singapura yang ditanam di Kebun Raya Bogor. Pada awal abad ke-20, pembangunan perkebunan karet besar-besaran dilakukan di Asia Tenggara sebagaimana dilaporkan oleh Jacques Huber, seorang botanist berkebangsaan Swiss (Castro et al., 2009).

Pada awal perkembangan perkebunan karet, karena pengetahuan mengenai spesies $H$. brasiliensis masih terbatas, penyadapan dilakukan tanpa pola hanya bertujuan untuk mendapatkan lateks sebanyakbanyaknya. Karena lateks diperoleh dengan cara melukai kulit tanaman, maka pendekatan yang ditempuh untuk meningkatkan produksi pada masa itu adalah dengan penggunaan banyak irisan bahkan sampai ke percabangan (Gambar 1A). Penggunaan banyak irisan tidak hanya diterapkan pada tanaman tua tapi juga pada tanaman muda yang produktif (Gambar 1B).

Penyadapan dengan banyak irisan cenderung menghambat translokasi asimilat. Meskipun partikel karet disintesis dalam sel laticifer, namum membutuhkan bahan baku asimilat yang ditranslokasikan melalui jaringan floem (de Fay et al., 1989). Penyadapan membuang sebagian besar jaringan floem sehingga pasokan asimilat menurun yang menyebabkan produksi terus menurun. Di samping itu, penyadapan dengan banyak irisan menyebabkan umur ekonomi pendek karena kulit habis dalam waktu singkat. Metode pemanenan ini ditinggalkan karena tidak sustainable untuk jangka panjang. Tapi di tingkat petani tradisional 
masih dijumpai penyadapan berlebihan seperti ini karena keterbatasan pengetahuan.
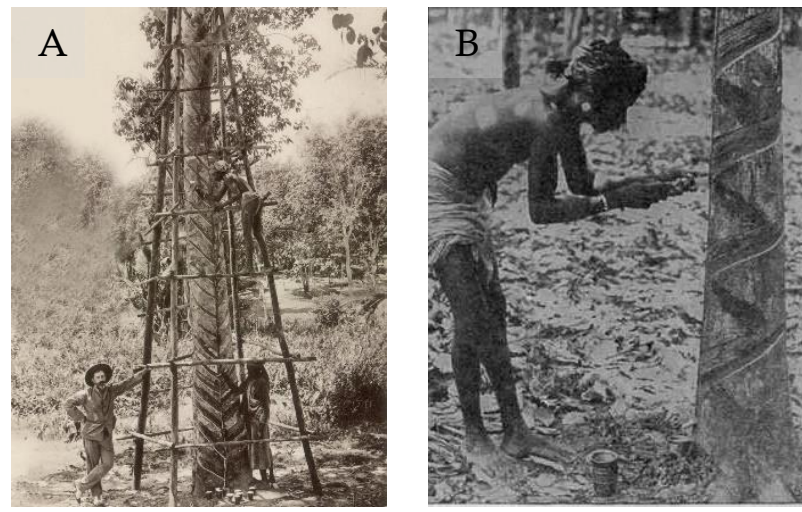

Gambar 1. Penyadapan karet pada periode awal perkebunan karet. Foto 1A: Royal Netherlands Institute of Southeast Asian and Caribean Studies and Leiden University Library. Foto 1B: the United States Rubber Co.

Dari banyak irisan, sistem sadap mengalami perubahan dengan menggunakan satu irisan (single cut) agar tanaman dapat dieksploitasi dalam jangka panjang. Sistem sadap ini bersifat sederhana dan menitikberatkan pada eksploitasi panel basal (B), baik kulit perawan (B0) maupun kulit pulihan (BI). Panel basal dieksploitasi berulang agar penyadapan dapat dilakukan dalam waktu yang panjang ( $\geq 25$ tahun), namun produksi menurun pada kulit pulihan sehingga produksi kumulatif kurang optimal (Sumarmadji et al., 2009). Frekuensi sadap dua hari sekali (d2) umum digunakan pada sistem sadap tradisional. Pada tahun 70-an mulai diperkenalkan stimulan (bahan kimia yang mengandung ethylene releaser) untuk meningkatkan produksi lateks. Peningkatan biaya tenaga kerja menyebabkan frekuensi sadap diturunkan menjadi tiga hari sekali (d3) dengan kompensasi pemberian stimulan lateks untuk mempertahankan produksi kumulatif tahunan. Efek penggunaan stimulan untuk meningkatkan produksi lateks telah banyak diteliti di antaranya oleh Zhu dan Zhang (2009), Dian et al. (2016), dan Dian et al. (2017). Di perkebunan besar milik negara maupun swasta, penggunaan stimulan telah menjadi bagian dari sistem pemanenan lateks, sedangkan di perkebunan rakyat belum semua petani mengadopsi teknologi ini.

\section{INOVASI TEKNIK PEMANENAN LATEKS}

Perkembangan penelitian membawa dampak signifikan terhadap kultur teknis tanaman karet. Penggunaan klon unggul hasil pemuliaan tanaman mampu meningkatkan potensi produksi tanaman. Dalam hal penyadapan, penelitian dan uji coba sistem pemanenan telah dilakukan untuk mendapatkan produksi lateks yang tinggi. Beberapa sistem sadap yang pernah diterapkan di perkebunan karet, dan sebagian masih diadopsi hingga saat ini antara lain sistem sadap tusuk, penyadapan ke arah atas, dan perpindahan antar panel.

\section{Sistem Sadap Tusuk}

Jika penyadapan pada umumnya dilakukan dengan mengiris kulit batang tanaman karet, pada sistem sadap tusuk lateks diperoleh dengan menusuk atau mengebor kulit di beberapa titik (Gambar 2). Penelitian sadap tusuk banyak dilakukan pada awal tahun 1980-an. Dengan sistem sadap ini diharapkan penyadapan dapat dilakukan dengan lebih cepat, efisien dalam penggunaan kulit, dan cekaman akibat pelukaan dapat diminimalisir. Karena pelukaan sangat minim, untuk mendapatkan lama aliran lateks yang memadai maka digunakan stimulan konsentrasi tinggi $(5.0 \%)$ atau bahkan menggunakan stimulan gas (Said dan Ramlan, 2006). Meskipun produksi yang dihasilkan cukup potensial, sebagaimana dilaporkan oleh Hamzah dan Gomez (1981) dan de Soyza dan Samaranayake (1983), namun penggunaan stimulan dengan dosis tinggi menyebabkan kerusakan jaringan kulit. Over-respons tanaman terhadap pelukaan dengan metode tusuk menimbulkan benjolan sehingga kulit tidak dapat disadap kembali. Saat ini sistem sadap tusuk tidak lagi diadopsi lagi dalam skala luas.

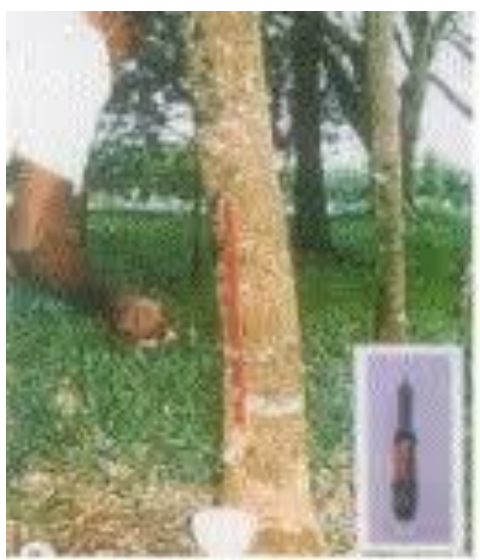

Gambar 2.Sistem sadap tusuk. Foto: Kerala Agricultural University (2019)

\section{Penyadapan Ke Arah Atas}

Hasil penelitian menunjukkan bahwa fotosintat (sukrosa) dari daun adalah bahan baku utama biosintesis partikel karet dalam sel laticifer. Selain itu, hasil pengamatan histologi kulit tanaman karet memberi gambaran penyebaran dan struktur jaringan laticifer. Fakta-fakta tersebut memberi peluang bahwa menyadap tanaman karet tidak harus ke arah bawah tapi juga dapat dilakukan ke arah atas (Gambar 3A). Modifikasi ini memiliki keuntungan karena aliran fotosintat ke derah drainase lateks di sekitar alur sadap tidak terputus oleh bekas irisan. Penelitian Obouayeba et al. (2008) pada klon GT 1 menunjukkan bahwa dibanding penyadapan setengan spiral ke arah bawah, produksi lateks meningkat $34 \%$ dengan penyadapan seperempat spiral dan $36 \%$ dengan irisan setengah spiral ke arah atas. Peningkatan 
produksi pada penyadapan ke arah atas yang dikombinasikan dengan aplikasi stimulan intensif juga dilaporkan oleh Dian et al. (2016). Penyadapan ke arah atas tetap diadopsi hingga saat ini terutama untuk mengoptimalkan produksi pada panel atas (HO) atau dikombinasikan dengan penyadapan kulit pulihan (BI) atau biasa disebut penyadapan ganda (double cut tapping system) (Gambar 3B).
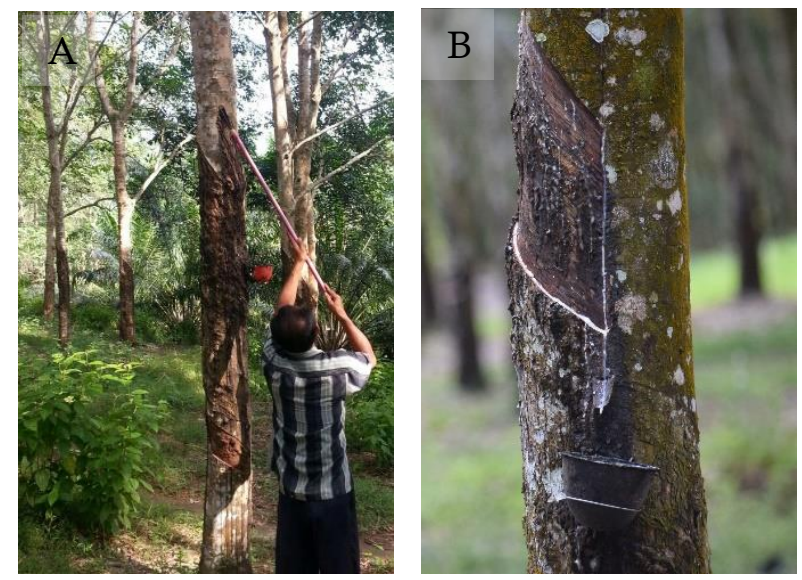

Gambar 3. Penyadapan ke arah atas (A, Foto: Junaidi et al. (2019)) dan panel sadap pada sadap ganda (B)

Nhean et al. (2017) melaporkan peningkatan produksi sebesar 14\% dengan penggunaan sistem sadap ganda tanpa stimulan di Thailand. Peningkatan produksi sistem sadap ini disebabkan tambahan produksi panel atas yang cukup signifikan. Namun demikian, menyadap ke arah relatif lebih sulit dibandingkan ke arah bawah terlebih ketika alur sadap sudah lebih dari $2 \mathrm{~m}$ dari permukaan tanah. Kendala lainnya adalah konsumsi kulit lebih boros dibanding sadap ke arah bawah (Junaidi et al., 2019). Meskipun untuk sadap atas telah digunakan pisau khusus, namun dengan tingkat kesulitan yang lebih tinggi, maka konsumsi kulit sulit dikontrol. Pada penyadapan ke arah atas, optimaslisasi produksi dapat dilakukan dengan memperhatikan faktor ketinggian, kemiringan, dan kedalaman sadapan (Herlinawati dan Kuswanhadi, 2012).

\section{Alternate Tapping Sistem dan Change Over Panel}

Alternate Tapping System (ATS) adalah sistem sadap yang mengadopsi perpindahan panel secara bergantian dalam satu sisi (panel) contohnya dari BI-1 pada semester I ke panel H0-1 pada semester II (Gambar 4A). Perpindahan juga dapat dilakukan ke panel sebelahnya secara bergantian atau biasa disebut Change Over Panel (COP), misalnya dari panel BI-1 ke panel H0-1, atau dari panel BI-1 ke panel H0-2, selanjutnya kembali ke panel BI-1 dan H0-1 seperti pada Gambar 4B. Secara prinsip, tataguna panel dapat mengoptimalkan produksi karena panel atas (H0) disadap pada periode daun penuh sedangkan panel bawah (BI) digunakan pada periode gugur daun. Kendala dalam implementasi konsep penyadapan ini adalah adaya kecenderungan penggunaan panel atas terus menerus karena produksi lebih tinggi sehingga meninggalkan panel bawah. Akibatnya panel atas lebih cepat habis dan umur ekonomis tanaman menjadi singkat. Saat ini, konsep ATS dan COP masih diadopsi di beberapa perkebunan dengan pengawasan yang ketat.
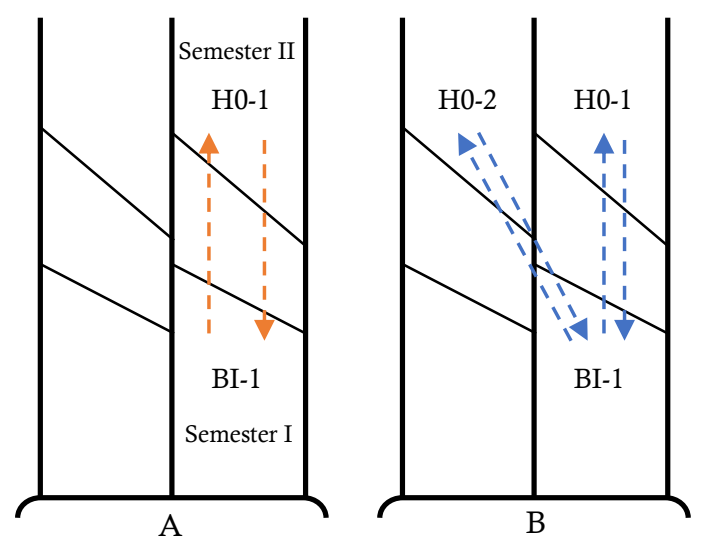

Sumber: Sumarmadji et al. (2009)

Gambar 4. Perpindahan panel mengadopsi pola ATS (A) dan COP (B)

\section{LATEKS DIAGNOSIS DAN PENYADAPAN TIPOLOGI KLONAL}

Pemuliaan tanaman karet telah menghasilkan klon-klon yang bervariasi (Priyadarshan et al., 2009; Daslin, 2014). Kegiatan pemuliaan tanaman karet di Indonesia telah menghasilkan klon-klon karet unggul generasi ke-V (Darojat dan Sayurandi, 2018). Proses seleksi juga melibatkan atribut penting lainnya seperti pertumbuhan (Daslin, 2013), ketahanan penyakit (Dalimunthe et al., 2015), dan adaptasi terhadap lingkungan sub-optimal (Priyadarshan, 2003). Diagnosis lateks dilakukan untuk meprediksi potensi produksi dan respon tehadap pemberian stimulan pada beberapa klon komersial (Gohet et al., 2003). Metode ini mengukur kadar sukrosa, fosfat anorganik, dan thiol. Kadar sukrosa adalah indikasi pasokan asimilat dalam jaringan laticifer, fosfat anorganik merupakan indikasi tingkat metabolisme tanaman terkait biosintesis karet, sedangkan thiol adalah indikasi cekaman yang dialami tanaman. Berdasarkan diagnosis lateks, klon karet dapat dikelompokkan ke dalam metabolisme rendah, tinggi, dan sedang. Klon metabolisme tinggi cenderung memiliki kadar fosfat anorganik yang tinggi di dalam lateks, sedangkan klon metabolisme rendah dan sedang cenderung memiliki kadar sukrosa yang tinggi. Contoh klon metabolisme tinggi antara lain IRR 112, IRR 118, PB 260, dan RRIM 712. Klon metabolisme sedang di antaranya klon RRIC 100, RRIM 600, dan BPM 24, sedangkan klon metabolisme rendah contohnya adalah GT 1, AVROS 2037, dan TM 9 (Sumarmadji et al., 2009).

Ada dua pendekatan dalam implementasi sistem sadap tipologi klonal. Pertama mengelompokkan klon- 
klon yang ada berdasarkan tingkat metabolismenya, selanjutnya tata guna panel, sistem sadap, dan aplikasi stimulan disusun dalam satu siklus tanaman. Untuk mempermudah teknis di lapangan, klon dibedakan menjadi klon metabolisme tinggi, biasa diistilahkan dengan klon quick starter (QS), dan metabolisme rendah dan sedang atau biasa disebut slow starter (SS). Klon QS responsif terhadap irisan ke arah atas tapi tidak responsif terhadap stimulan. Peningkatan produksi diperoleh saat penggunaan panel atas setelah 5 tahun penyadapan di panel bawah. Klon SS umumnya memiliki kulit pulihan tebal dan potensial serta responsif terhadap stimulan. Peningkatan produksi diperoleh dengan penggunaan sadap ganda setelah 10 tahun penyadapan di panel bawah. Dengan perbedaan sistem sadap tersebut, kedua kelompok klon tersebut memiliki tren produksi berbeda dalam satu siklus ekonomi (Gambar 5) (Bukit et al., 2006). Karena perbedaan tersebut, seringkali terjadi kesalahpahaman bahwa klon QS adalah klon yang memiliki puncak produksi di depan sedangkan klon SS di belakang. Dalam artikel-artikel mengenai penyadapan dan kajian fisiologis karet, QS dan SS merujuk pada tingkat metabolisme tanaman bukan tren produksi dalam satu siklus ekonomi.

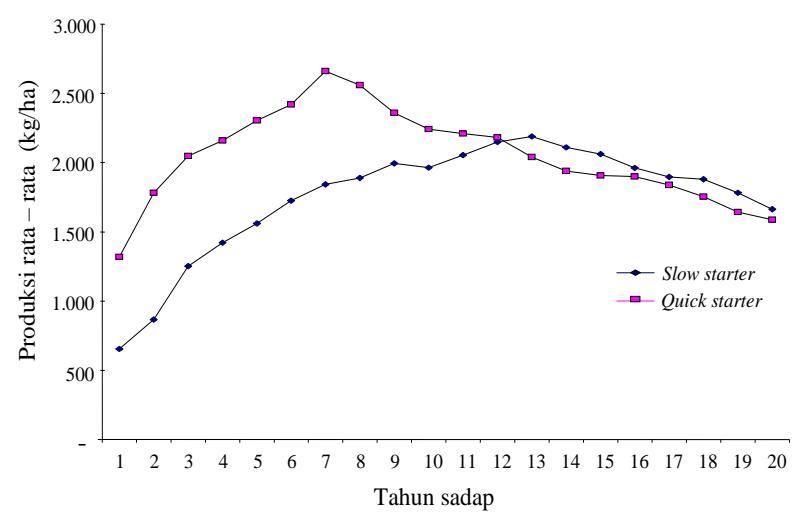

Sumber: Bukit et al. (2006)

Gambar 5. Tren produksi klon quick starter dan Slow starter

Pendekatan kedua adalah menggunakan informasi dari diagnosis lateks untuk mengoptimalkan penggalian produksi melalui peningkatan penggunaan stimulan baik frekuensi maupun dosisnya. Dengan pendekatan ini, tata guna panel tidak dibedakan antar kelompok klon melainkan aplikasi stimulannya saja. Untuk memantau kondisi tanaman, diagnosis lateks dilakukan secara berkala, selanjutnya sistem sadap termasuk tata guna panel dan aplikasi stimulan disesuaikan berdasarkan hasil diagnosis lateks. Diagnosis lateks menjadi dasar pengelompokan klon sedangkan penerapannya dapat menggunakan pendekatan yang berbeda.

Selain menjadi dasar pengelompokan klon dan optimalisasi produksi, diagnosis lateks diharapkan juga dapat digunakan untuk mencegah kering alur sadap (KAS). Namun kadar thiol sebagai parameter penduga kondisi fisiologis tanaman sangat rentan terhadap kondisi lingkungan. Inkonsistensi kadar thiol dengan tingkat cekaman yang dialami tanaman dilaporkan di beberapa artikel antara lain oleh Herlinawati dan Kuswanhadi (2013), Putranto et al. (2015), dan Purwaningrum et al., 2019). Kendala lain adalah diagnosis lateks membutuhkan peralatan laboratorium yang memadai, metode analisis yang cermat, dan intrepetasi data yang kompleks sehingga tidak semua perkebunan dapat mengadopsi metode ini. Saat ini, diagnosis lateks masih terbatas dilakukan oleh perkebunan negara dan swasta yang mapan, sedangkan perkebunan karet rakyat belum mengadopsi metode ini.

\section{KONDISI AGRIBISNIS KARET SAAT INI}

Harga karet alam mulai mengalami penurunan pada tahun 2012, sampai saat ini harga cenderung stagnan. Bahkan, Baffes dan Wu (2018) mencatat pada periode Juli 2017 - Desember 2018, harga karet mengalami titik terendah pada Desember 2018 (Gambar 6). Selama tahun 2019, harga karet belum mengalami peningkatan yang signifikan (Pai, 2019). Akibat harga karet yang rendah, banyak kebun karet rakyat yang dibiarkan tidak disadap karena pendapatan dari hasil kebun karet tidak memadai untuk kebutuhan sehari-hari. Petani lebih memilih meninggalkan kebun karetnya dan sementara memilih profesi lain yang lebih menjanjikan. Bagi perusahaan perkebunan, penuruan harga jual berarti penurunan pendapatan. Kondisi ini diperparah dengan upah tenaga kerja yang terus meningkat.

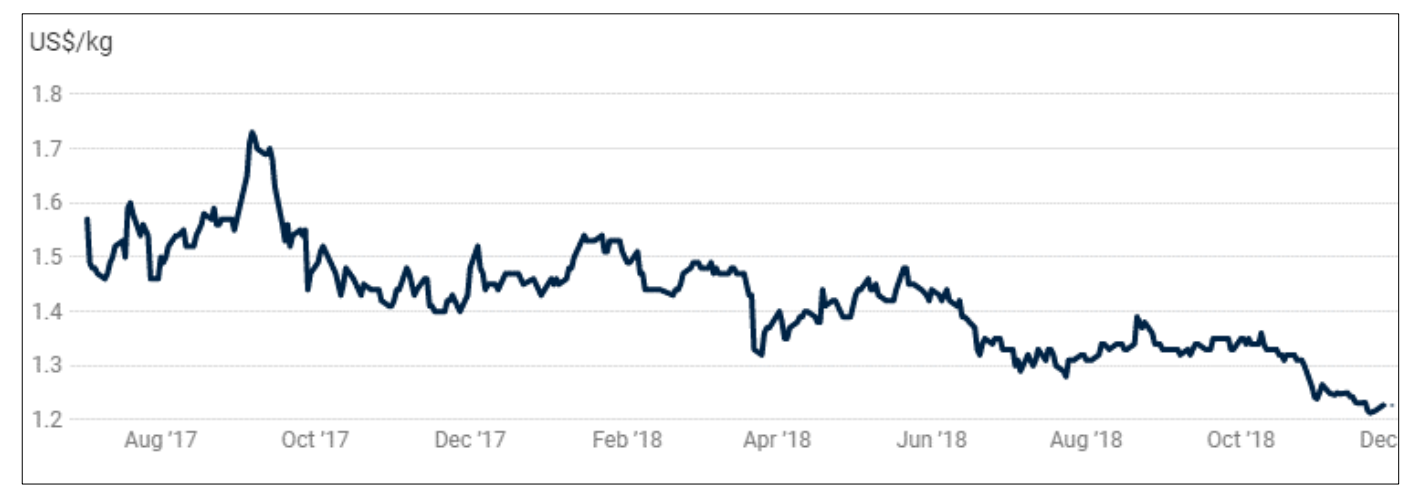

Sumber: Baffes dan Wu (2018)

Gambar 6. Perkembangan harga karet pada periode Juli 2017 - Desember 2018 
Tenaga kerja merupakan komponen biaya paling besar di perkebunan karet, mencapai $\pm 61 \%$ dari total biaya operasional (Gambar 7) (Hirohata dan Fukuyo, 2011; Hirohata, 2015). Dari total biaya tenaga kerja, tenaga penyadap termasuk komponen paling besar karena pada frekuensi sadap d3 misalnya, dibutuhkan 0,3 penyadap/ha atau kurang lebih 30 penyadap/100 hektar tanaman (Agustina et al., 2013). Untuk mengurangi biaya tenaga kerja, dua pendekatan dilakukan bersamaan yaitu menambah jumlah pohon per hanca agar produksi harian di atas biaya penyadapan dan menurunkan frekuensi penyadapan.

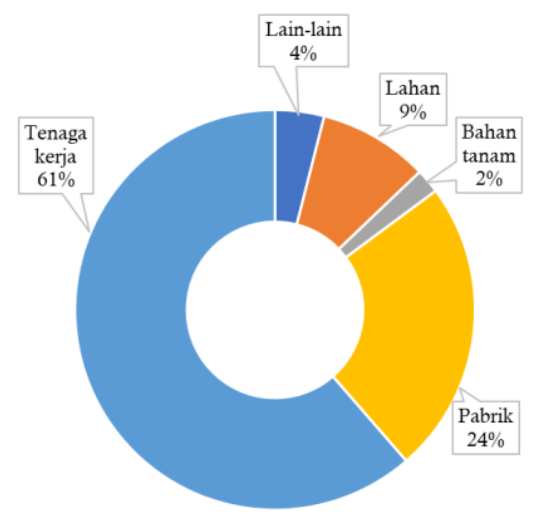

Sumber: Hirohata (2015)

Gambar 7. Komponen biaya produksi karet

Harga karet yang rendah juga berdampak pada kegiatan kultur teknis di lapangan. Dalam kondisi ini, umumnya perusahaan melakukan efisiensi biaya untuk menjaga harga pokok penjualan. Di beberapa perusahaan, kegiatan pemeliharaan termasuk pemupukan, pengendalian gulma dan hama penyakit terpaksa dikurangi baik frekuensi maupun dosisnya. Efisiensi biaya pemeliharaan dalam jangka pendek tidak akan langsung produksi lateks, karena sejatinya tanaman karet adalah tanaman hutan yang memiliki toleransi terhadap input luar yang rendah. Efek pengurangan input akan lebih terlihat pada parameter pertumbuhan akibat berkurangnya asupan hara dan kompetisi dengan gulma selain itu ketahanan terhadap penyakit akibat berkurangnya frekuensi pengendalian patogen. Dalam jangka panjang, kesehatan tanaman akan mempengaruhi produksi lateks.

\section{SISTEM SADAP FREKUENSI RENDAH}

Penurunan frekuensi penyadapan bukan hal baru. Sebelum frekuensi sadap d3 dengan stimulan etefon diadopsi secara luas, penyadapan $\mathrm{d} 2$ tanpa stimulan merupakan sistem sadap yang umum. Sistem sadap frekuensi rendah berarti menggunakan frekuensi penyadapan lebih rendah dari $\mathrm{d} 3$, misalnya $\mathrm{d} 4$, d5 atau d6. Tingginya biaya tenaga kerja merupakan faktor utama penerapan sistem sadap ini. Pada prinsipnya, semakin rendah frekuensi sadap, maka tenaga penyadap yang dibutuhkan semakin sedikit (Gambar 8). Agustina et al. (2013) melaporkan bahwa kebutuhan tenaga penyadap dengan frekuensi d4 adalah 0,25 orang/ha, lebih rendah dibanding frekuensi d3 ( 0,3 orang/ha). Perhitungan ini berdasarkan asumsi bahwa setiap penyadap dapat menyelesaikan penyadapan satu hektar per hari. Dibanding frekuensi sadap d2, penurunan biaya penyadapan dengan frekuensi d3 mencapai 16,0 - 29,0\%, sedangkan dengan frekuensi $\mathrm{d} 4, \mathrm{~d} 5$, dan d6 masingmasing sebesar $37,0-45,0 \%, 53,0-54,0 \%$, dan $60,0-$ 61,0\% (Nugrahani et al., 2017).

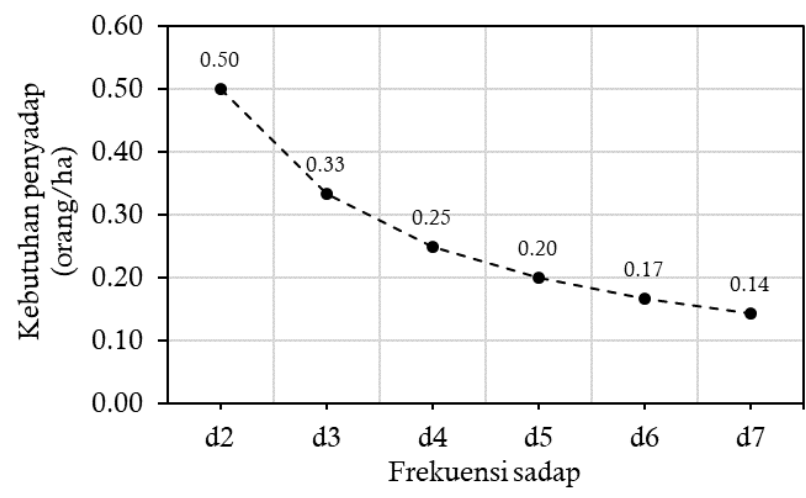

Diadopsi dari Agustina et al. (2013)

Gambar 8. Kebutuhan tenaga penyadap dengan beberapa skenario frekuensi sadap

Sistem sadap frekuensi rendah juga telah diuji coba di negara-negara penghasil karet lainnya di antaranya Myanmar (Zaw et al., 2017), Sri Lanka (Kudaligama et al., 2010), Thailand (Sainoi et al., 2017), dan Pantai Gading (Soumahin et al., 2009). Hasil penelitian Nugrahani et al. (2017) menunjukkan bahwa produksi klon PB 260 dengan frekuensi sadap d4 dikombinasikan dengan konsentrasi stimulan tinggi $(5,0 \%)$ lebih tinggi dibanding frekuensi d3, d5, dan d6 dengan beberapa kombinasi perlakuan stimulan. Namun demikian, produksi kumulatif dalam kilogram per hektar per tahun (kg/ha/th) lebih rendah dibanding d3 (Tabel 1). Hal ini disebabkan pengurangan hari sadap per tahun yang cukup signifikan.

Penelitian lain oleh Soumahin et al. (2009) pada klon GT 1 menunjukkan bahwa peningkatan konsentrasi dan frekuensi aplikasi stimulan tidak selalu berbanding lurus dengan produktivitas tanaman. Hal ini menunjukkan bahwa pada penerapan sistem sadap frekuensi rendah, produktivitas tanaman bervariasi tergantung banyak faktor di antaranya umur tanaman, jenis klon (tingkat metabolisme), agroklimat, dan kesehatan tanaman. Dalam kondisi harga karet yang rendah, sistem sadap frekuensi rendah adalah pilihan yang rasional, namun dalam penerapannya perlu diperhitungkan kemungkinan penurunan produksi kumulatif dan efisiensi biaya penyadapan yang diharapkan. 
Tabel 1. Produksi tanaman karet klon PB 260 yang disadap dengan beberapa frekuensi dan konsentrasi stimulan

\begin{tabular}{|c|c|c|c|c|c|c|}
\hline \multirow{2}{*}{$\begin{array}{l}\text { Frekuensi } \\
\text { sadap }\end{array}$} & \multirow[t]{2}{*}{ Stimulansia } & \multirow{2}{*}{$\begin{array}{c}\text { Hari } \\
\text { sadap }\end{array}$} & \multicolumn{2}{|c|}{$\begin{array}{l}\text { Produktivitas } \\
\text { tanaman }\end{array}$} & \multicolumn{2}{|c|}{$\begin{array}{l}\text { Produksi } \\
\text { kumulatif }\end{array}$} \\
\hline & & & $\mathrm{g} / \mathrm{p} / \mathrm{s}$ & $\%$ & $\mathrm{~kg} / \mathrm{ha} / \mathrm{th}$ & $\%$ \\
\hline $\mathrm{S} / 2 \mathrm{~d} 3(\mathrm{C})$ & ET2.5\% Ga1.0 (2w) (C) & 120 & 21,4 & 100,00 & 1.286 & 100,00 \\
\hline $\mathrm{S} / 2 \mathrm{~d} 3$ & ET2.5\% Ga1.0 (m/3) & 120 & 25,1 & 117,29 & 1.505 & 117,03 \\
\hline $\mathrm{S} / 2 \mathrm{~d} 3$ & ET4.0\% Ga1.0 (2w) & 120 & 24,6 & 114,95 & 1.478 & 114,93 \\
\hline $\mathrm{S} / 2 \mathrm{~d} 3$ & ET5.0\% Ga1.0 (2w) & 120 & 19,7 & 92,06 & 1.179 & 91,68 \\
\hline $\mathrm{S} / 2 \mathrm{~d} 4$ & ET4.0\% Ga1.0 (2w) & 90 & 27,1 & 126,64 & 1.220 & 94,87 \\
\hline $\mathrm{S} / 2 \mathrm{~d} 4$ & ET5.0\% Ga1.0 (2w) & 90 & 30,9 & 144,39 & 1.390 & 108,09 \\
\hline $\mathrm{S} / 2 \mathrm{~d} 5$ & ET4.0\% Ga1.0 (2w) & 72 & 23,4 & 109,35 & 843 & 65,55 \\
\hline $\mathrm{S} / 2 \mathrm{~d} 5$ & ET5.0\% Ga1.0 (2w) & 72 & 28,0 & 130,84 & 1.008 & 78,38 \\
\hline $\mathrm{S} / 2 \mathrm{~d} 6$ & ET4.0\% Ga1.0 (2w) & 60 & 27,2 & 127,10 & 816 & 63,45 \\
\hline $\mathrm{S} / 2 \mathrm{~d} 6$ & ET5.0\% Ga1.0 (2w) & 60 & 27,8 & 129,91 & 833 & 64,77 \\
\hline
\end{tabular}

Keterangan: C: kontrol; g/p/s: gram/pohon/sadap; kg/ha/th: kilogram/hektar/tahun; asumsi kerapatan tanaman: 500 pohon/ha. Diadopsi dari Nugrahani et al. (2017)

\section{SISTEM SADAP DI MASA DEPAN}

Dalam skala agribisnis, penyadapan tanaman karet melibatkan banyak faktor yang harus dipertimbangkan, antara lain: harga komoditi, ketersediaan tenaga kerja, kondisi tanaman, cekaman akibat penyadapan, fenologi, agroklimat, dan kesehatan tanaman. Kondisi agribisnis karet saat ini menghendaki capaian produksi tinggi dengan biaya yang efisien. Hal ini merupakan tantangan tersendiri bagi para praktisi agribisnis karet untuk menentukan sistem sadap yang sesuai. Berbagai sistem sadap yang telah diuji coba dan studi fisiologis meletakkan dasar pemikiran bahwa:

1. Produksi tinggi yang diharapkan adalah produksi yang berkelanjutan dalam satu siklus ekonomi tanaman bukan produksi dalam jangka pendek.

2. Teknis penyadapan tidak terpaku pada satu cara panen, melainkan dapat dilakukan dengan berbagai metde untuk mendapatkan lateks.

3. Setiap klon memiliki karakteristik metabolisme yang berbeda dan menghendaki cara panen yang berbeda pula.

4. Sistem sadap bersifat fleksibel, dapat berubah dan disesuaikan sesuai kebutuhan dan kondisi tanaman.

5. Optimasi produksi hanya dapat dilakukan jika kondisi fisiologis tanaman masih memungkinkan.

Biaya tenaga kerja diperkirakan akan terus meningkat. Frekuensi sadap d3 yang umum digunakan saat ini, terutama di perkebunan besar, sepertinya perlahan akan digantikan oleh frekuensi yang lebih rendah dengan kompensasi peningkatan konsentrasi dan frekuensi stimulan. Dalam hal ini, pemilihan klon menjadi sangat krusial. Klon metabolisme rendah dan sedang, yang responsif terhadap stimulan dinilai lebih sesuai dibandingkan klon metabolisme tinggi.

Peran diagnosis lateks dalam memonitor kondisi fisiologis tanaman menjadi faktor kunci optimasi produksi. Sejauh ini, parameter kadar sukrosa dan fosfat anorganik cukup akurat untuk evaluasi sistem sadap yang diterapkan, namun parameter kadar thiol untuk menduga tingkat cekaman masih inkonsisten. Ditambah lagi, diagnosis lateks masih sulit diadopsi oleh seluruh perkebunan. Di masa yang akan datang, pemanfaatan teknologi sensorik dan instrumen digital portable kemungkian akan lebih banyak digunakan untuk pengamatan di lapangan, meskipun analisis di laboratorium tetap diperlukan untuk kalibrasi. Salah satu teknologi yang banyak diteliti saat ini adalah penggunaan near infra-red spectroscopy (NIRS). Metode ini dilaporkan cukup akurat menduga kadar air lum (Suchat et al., 2015), kadar karet kering (KKK) lateks (Sirisomboon et al., 2013), dan sifat mekanis kompon karet (Pornprasit et al., 2018). Teknologi lainnya adalah Loop-mediated Isothermal Amplification (LAMP) yang telah digunakan untuk mendeteksi serangan Colletotrichum gloeosporioides (Wang et al., 2017) dan Fusarium (Lu et al., 2015). Teknologi ini kemungkinan dapat diadopsi untuk mendeteksi cekaman oksidatif akibat penyadapan.

Penggunaan teknologi memungkinkan untuk memonitor kondisi tanaman setiap saat sehingga di masa yang akan datang sistem sadap menjadi sangat fleksibel. Sistem sadap tidak lagi dirancang untuk satu siklus ekonomi melainkan bersifat kondisional tergantung kondisi tanaman, fenologi, dan tuntutan produksi. Namun demikian, kemajuan dalam sistem pemanenan lateks tidak diikuti oleh rekayasa alat sadap. Dari awal perkembangan perkebunan karet sampai saat ini, penyadapan dilakukan menggunakan pisau sadap manual. Meskipun beberapa prototipe dan produk telah dihasilkan antara lain semi automatic rubber tree tapping machine (SART) (Soumya et al., 2016), 4GXJ-I tapping knife (Huang et al., 2019), dan Appuhamy (Yatawara et al., 2019) namun sejauh ini belum diterapkan dalam skala luas. Melihat kenyataan ini, pisau sadap manual yang digunakan saat ini sepertinya masih akan tetap digunakan secara luas untuk waktu yang lama.

\section{KESIMPULAN}

Sistem pemanenan lateks tanaman karet terus mengalami pembaharuan. Penyadapan karet yang awalnya menggunakan banyak irisan berubah menjadi satu irisan untuk memperpanjang umur ekonomis 
tanaman. Penggunaan stimulan merubah secara signifikan sistem penyadapan karet dari d2 tanpa stimulan menjadi d3 dengan stimulan. Dalam hal teknik penyadapan, sistem sadap tusuk pernah dikembangkan namun kurang berhasil. Modifikasi penyadapan yang masih diadopsi hingga sekarang adalah penyadapan ke arah atas dan sadap ganda. Kemajuan di bidang penelitian fisiologis tanaman menghasilkan metode diagnosis lateks yang berguna untuk mengoptimalkan potensi klon. Metode ini mulai diadopsi terutama oleh perkebunan-perkebunan besar. Harga karet yang rendah dalam delapan tahun terakhir merubah cara pandang perusahaan perkebunan terhadap sistem sadap yang digunakan. Efisiensi tenaga kerja melalui penerapan sistem sadap frekuensi rendah menjadi pilihan di tengah kondisi sulit saat ini. Di masa yang akan datang, sistem sadap frekuensi rendah akan menjadi pilihan utama karena upah tenaga kerja yang terus meningkat. Selain itu, penggunaan teknologi sensorik dan instrumen digital mulai banyak diteliti. Melihat fakta-fakta ini, sistem pemanenan lateks pada tanaman karet diyakini akan terus berkembang.

\section{DAFTAR PUSTAKA}

Agustina, D.S., E. Herlinawati, and M. Aji. 2013. Financial analyses on $\mathrm{d} 4$ tapping as alternative to d3 in rubber plantation of South Sumatra. International Rubber Conference 2017: 841-849.

Atminingsih, R. Tistama, Junaidi, and I. Saban. 2019. The effect of high stimulant concentration on the yield and dry rubber content of high metabolic clone RRIM 911 in low-tapping frequency practice. AGRIUM: Jurnal Ilmu Pertanian 22: 1117. DOI: 10.30596/agrium.v21i3.2456

Baffes, J., and J. Wu. 2018. Raw materials outlook: cotton, rubber prices to stabilize in 2019. World Bank Blogs. http://blogs.worldbank.org/developmenttalk/rawmaterials-outlook-cotton-rubber-prices-stabilize2019

Bukit, E., A.D. Sagala, and Karyudi. 2006. Kajian ekonomi penggunaan klon karet anjuran Quick starter dan Slow starter. Prosiding Lokakarya Nasional Budidaya Tanaman Karet, Medan 4-6 September 2006.

Castro, A.R. de M., N. Sanjad, and D. dos S. Romeiro 2009. From rubber tree homeland to rubber tree plantation: Jacques Huber and his studies on the culture of heveas in the East (1911-1912). Boletimdo Museu Paraense 4: 503-545. DOI: 10.1590/S1981-81222009000300011

Dalimunthe, C.I., Z. Fairuzah, dan A. Daslin. 2015. Ketahanan lapangan tanaman karet klon IRR seri 100 terhadap tiga patogen penting penyakit gugur daun. Jurnal Penelitian Karet 33: 35-46. DOI: 10.22302/jpk.v33i1.169

Darojat, M.R. dan Sayurandi. 2018. Status klon-klon karet seri IRR hasil kegiatan pemuliaan Indonesia dan adopsinya di perkebunan karet Indonesia.
Perspektif 17: 150-165. DOI: 10.21082/psp.v17n2.2018

Daslin, A. 2013. Produktivitas klon karet pada berbagai kondisi lingkungan di perkebunan. AGRIUM: Jurnal Ilmu Pertanian 18: 1-6. DOI: 10.30596/agrium.v18i1.337

Daslin, A. 2014. Perkembangan penelitian klon karet unggul IRR seri 100 sebagai penghasil lateks dan kayu. Warta Perkaretan 33: 1-10. DOI: 10.22302/ppk.wp.v33i1.44

de Fay, E., C. Sanier, and C. Hebant. 1989. The distribution of plasmodesmata in the phloem of Hevea brasiliensis in relation to laticifer loading. Protoplasma 149: 155-162.

de Soyza, A.G.A. and C. Samaranayake. 1983. Effect of puncture vs conventional tapping on the yield and girth of Hevea. Journal of Rubber Research Institute of Sri Langka 61: 7-16.

Dian, K., M.K. Okoma, M.Y. Gnagne, R.O. Gabla, and S. Obouayeba. 2016. Impact of intensive stimulation with ethephon in downward tapping on the potential of production in upward tapping in GT 1 clone of Hevea brasiliensis. International Journal of Current Science 19: E11-23.

Dian, K., M.Y. Gnagne, M.K. Okoma, and A. Sagare. 2017. Effect of ethephon stimulation on downward tapping in latex production metabolism on upward tapping in PB 217 clone of Hevea Brasiliensis. International Journal of Environment, Agriculture and Biotechnology 2: 2944-2957. DOI: 10.22161/ijeab/2.6.22

Gohet, E., P. Chantuma, R. Lacote, S. Obouayeba, A. Clement-Demange, D. Kurnia, and M. Eschbach. 2003. Latex clonal typology of Hevea brasiliensis: physiological modelling of yield potential and clonal response to ethephon stimulation. Proceedings of the International Workshop on Exploitation Technology, Kottayam 15-18 December 2003, 199-216.

Gronover, C.S., D. Wahler, and D. Prufer. 2011. Natural rubber biosynthesis and physic-chemical studies on plant derived latex. In Prof. Magdy Elnashar (Ed.). Biotechnology of Biopolymers (pp. 75-88). InTech. http://cdn.intechweb.org/pdfs/16198.pdf

Hamzah, S., and J.B. Gomez. 1981. Anatomy of bark renewal in normal puncture tapped trees. Journal of Rubber Research Institute of Malaysia 29: 8695.

Herlinawati, E. dan Kuswanhadi. 2012. Beberapa aspek penting pada penyadapan panel atas tanaman karet. Warta Perkaretan 31: 66-74. DOI: 10.22302/ppk.wp.v31i2.268

Herlinawati, E., dan K. Kuswanhadi. 2013. Aktifitas metabolisme beberapa klon karet pada berbagai frekuensi sadap dan stimulasi. Jurnal Penelitian Karet 31: 110. DOI: 10.22302/jpk.v31i2.138

Hirohata, N. 2015. A survey on the competitiveness of natural rubber companies in Mekong sub-region. IFEAMA SPSCP 4: 72-79. http://ifeama.org/ifeamaspscp/selected papers/12th 
in Hanoi/12th 07 Hirohata_Final .pdf

Hirohata, N. and K. Fukuyo. 2011. Comparative study of large-scale investment in plantation in least developed countries applying the investment profitability analysis model. Proceedings of the 8Th International Conference on Innovation and Management 1: 370-374.

Huang, C., L. Wang, J. Cao, Y. Zheng, and S. Wu. 2019. The technology research on cutting test of 4GXJ-I tapping knife for rubber tree. IOP Conference Series: Materials Science and Engineering 592: 012070. DOI: 10.1088/1757-899X/592/1/012070

Junaidi, A. and M.R. Darojat. 2019. Direction, panel height, and tapping frequency affect the daily bark consumption in Hevea rubber tapping. Planta Tropika: Journal of Agro Science 7: 58-65. DOI: 10.18196/pt.2019.094.58-65

Kerala Agricultural University. 2019. Rubber (Hevea brasiliensis): Crop Management. KAU AgriInfotech Portal.

http://www.celkau.in/Crops/Plantation

Crops/Rubber/harvesting.aspx

Kudaligama, K.V.V.S., V.H.L. Rodrigo, K.M.E.P. Fernando, \& P.A.J. Yapa. 2010. Response of low frequency harvesting systems of rubber under drier climatic conditions in Sri Lanka. Proceedings of the 15th International Forestry and Environment Symposium, University of Sri Jayewardenepura. Sri Lanka, 26-27 November 2010, 62-69. http://journals.sjp.ac.lk/index.php/fesympo/article/ view/163/70

Lacote, R., A. Doumbia, S. Obouayeba, and E. Gohet. 2013. Sustainable rubber production through good latex harvesting practices: stimulation based on clonal latex functional typology and tapping panel management. IRRDB Workshop on Latex Harvesting Technology, Binh Duong, 19-22 November 2013, 1-18.

Lu, C., H. Zhang, Y. Wang, and X. Zheng. 2015. Rapid diagnosis of Fusarium root rot in soybean caused by Fusarium equiseti or Fusarium graminearum using loop-mediated isothermal amplification (LAMP) assays. Australasian Plant Pathology 44: 437-443. DOI: 10.1007/s13313-015-0361-8

Nhean, S., S.I.N. Ayutthaya, P. Songsrn, S. Gonkhamdee, and S. Sdoodee. 2017. Efficiency of double cut alternative tapping system to improve latex productivity of rubber tree clone RRIT 251 in marginal area, Thailand. Asia-Pacific Journal of Science and Technology 22: 1-6.

Nugrahani, M.O., A. Rouf, Y.B.S. Aji, T. Widyasari, dan N.D. Rinojati. 2017. Kombinasi sisten sadap frekuensi rendah dan penggunaan stimulan untuk optimasi produksi dan penurunan biaya penyadapan di panel BO. Jurnal Penelitian Karet, 35: 59-70. DOI: 10.22302/ppk.jpk.v1i1.350

Obouayeba, S., E.F. Soumahin, A.M.C. Boko, G.B. Dea, K. Dian, and Y.M. Gnagne. 2008. Improvement of productivity of rubber trees in smallholding by the introduction of upward tapping in the south-east of
Cote d'Ivoire. Journal of Rubber Research 11: 163-170.

Pai, A.V. 2019. Recent trends in natural rubber. Geojit Foresight. https://blog.geojit.com/recent-trends-innatural-rubber/

Perumal, V., N. Geetha, S. Palanivel, and A. Thulaseedharan. 2013. Natural rubber producing plants: An overview. African Journal of Biotechnology 12: 1297-1310. DOI: 10.5897/AJBX12.016

Pornprasit, R., P. Pornprasit, P. Boonma, and J. Natwichai. 2018. A study on prediction performance of the mechanical properties of rubber using Fourier-transform near infrared spectroscopy. Journal of Near Infrared Spectroscopy 26: 351-358. DOI: $10.1177 / 0967033518805277$

Prado, E. and D. Demarco. 2018. Laticifers and Secretory Ducts: Similarities and Differences. In Ecosystem Services and Global Ecology (pp. 103-123). InTech. DOI: 10.5772/intechopen.75705

Priyadarshan, P.M. 2003. Breeding Hevea brasiliensis for environmental constraints. Advances in Agronomy 79: 351-400. DOI: 10.1016/S00652113(02)79007-X

Priyadarshan, P.M. 2011. Biology of Hevea Rubber. CAB International. DOI: 10.1007/978-3-31954506-6

Priyadarshan, P.M., P.S. Goncalves, and K.O. Omokhafe. 2009. Breeding of Hevea rubber. In: S. M. Jain and P.M. Priyadarshan (Eds.), Breeding Plantation Tree Crops: Tropical Species (pp. 469522). Springer Nature. DOI: 10.1007/978-0-38771201-7

Purwaningrum, Y., Y. Asbur, and Junaidi. 2019. Latex quality and yield parameters of Hevea brasiliensis (Willd. ex A. Juss.) Müll. Arg. clone PB 260 for different tapping and stimulant application frequencies. Chilean Journal of Agricultural Research, 79: 347-355. DOI: 10.4067/S071858392019000300347

Putranto, R.A., E. Herlinawati, M. Rio, J. Leclercq, P. Piyatrakul, E. Gohet, C. Sanier, F. Oktavia, J. Pirrello, Kuswanhadi, and P. Montoro. 2015. Involvement of ethylene in the latex metabolism and tapping panel dryness of Hevea brasiliensis. International Journal of Molecular Sciences 16: 17885-17908. DOI: 10.3390/ijms160817885

Said, M.A. and M.F. Ramlan. 2006. Relationship between methods of latex extraction and stimulation on yield of RRIM 901, panel B0-1. Journal of Rubber Research 9: 238-250.

Sainoi, T., S. Sdoodee, R.R. Lacote, and E. Gohet. 2017. Low frequency tapping systems applied to youngtapped trees of Hevea brasiliensis (Willd. ex A. Juss.) Müll. Arg. in Southern Thailand. Agriculture and Natural Resources 51: 268-272. DOI: 10.1016/J.ANRES.2017.03.001

Simmons, B. 2008. Book Review: "The Thief at the End of the World”, Henry Wickham's adventures. The 
Seattle

Times.

https://www.seattletimes.com/entertainment/book s/the-thief-at-the-end-of-the-world-henrywickhams-adventures/

Sirisomboon, P., M. Deeprommit, W. Suchaiboonsiri, and W. Lertsri. 2013. Shortwave near infrared spectroscopy for determination of dry rubber content and total solids content of para rubber (Hevea Brasiliensis) latex. Journal of Near Infrared Spectroscopy 21: 269-279. DOI: 10.1255/jnirs.1061

Soumahin, E.F., S. Obouayeba, and P.A. Anno. 2009. Low tapping frequency with hormonal stimulation on Hevea brasiliensis clone PB 217 reduces tapping manpower requirement. Journal of Animal \& Plant Sciences 2: 109-117. http://www.biosciences.elewa.org/JAPS;

Soumya, S.J., R.S. Vishnu, R.N. Arjun, and R.R. Bhavani. 2016. Design and testing of a semi automatic rubber tree tapping machine (SART). 2016 IEEE Region 10 Humanitarian Technology Conference (R10-HTC), 1-4. DOI: 10.1109/R10HTC.2016.7906779

Suchat, S., P. Theanjumpol, and S. Karrila. 2015. Rapid moisture determination for cup lump natural rubber by near infrared spectroscopy. Industrial Crops and Products 76: 772-780. DOI: 10.1016/j.indcrop.2015.07.070

Sumarmadji, Junaidi, dan Atminingsih. 2009. Perkembangan sistem eksploitasi dalam upaya pencapaian produktivitas optimal. Warta Perkaretan 28: 60-72.

Sumarmadji, Junaidi, Atminingsih, Kuswanhadi, dan A. Rouf. 2012. Paket teknologi penyadapan untuk optimasi produksi sesuai tipologi klon. Prosiding Konferensi Nasional Karet, Yogyakarta 19 - 20 September 2012, 207-216.

van Beilen, J.B. and Y. Poirier. 2007. Guayule and Russian dandelion as alternative sources of natural rubber. Critical Reviews in Biotechnology 27: 217 231. DOI: 10.1080/07388550701775927

Wang, S., W. Ye, Q. Tian, S. Dong, and X. Zheng. 2017. Rapid detection of Colletotrichum gloeosporioides using a loop-mediated isothermal amplification assay. Australasian Plant Pathology 46: 493-498. DOI: $10.1007 / \mathrm{s} 13313-017-0511-2$

Yatawara, Y.A.I., W.H.C. Brito, M.S.S. Perera, and D.N. Balasuriya. 2019. "Appuhamy" - the fully automatic rubber tapping machine. Engineer: Journal of the Institution of Engineers, Sri Lanka 52: 27-33. DOI: 10.4038/engineer.v52i2.7351

Zaw, Z.N., S. Sdoodee, and R. Lacote. 2017. Performances of low frequency rubber tapping system with rainguard in high rainfall area in Myanmar. Australian Journal of Crop Science 11: 1451-1456. DOI: 10.21475/ajcs.17.11.11.pne593

Zhu, J. and Z. Zhang. 2009. Ethylene stimulation of latex production in Hevea brasiliensis. Plant Signaling \& Behavior 4: 1072-1074. DOI: 10.1016/j.plaphy.2009.06.003 